\title{
Antimicrobial Activity and Phytochemical Analysis of Aqueous and Ethanolic Extracts of the Bark of Tabernaemontena pachysiphon Stapf
}

\author{
Duru C. M. ${ }^{1}{ }^{\text {* }}$, Anyadoh-Nwadike S. O. ${ }^{2}$, Okechukwu R. I. ${ }^{1}$ \\ ${ }^{1}$ Department of Biological Science, Federal University of Technology, Owerri, Imo State, Nigeria \\ ${ }^{2}$ Department of Biotechnology, Federal University of Technology, Owerri, Imo State, Nigeria
}

Email address:

kristovad@yahoo.com (Duru C. M.), sylanyad@yahoo.com (Anyadoh-Nwadike S. O.)

\section{To cite this article:}

Duru C. M., Anyadoh-Nwadike S. O., Okechukwu R. I.. Antimicrobial Activity and Phytochemical Analysis of Aqueous and Ethanolic Extracts of the Bark of Tabernaemontena pachysiphon Stapf. Science Journal of Public Health. Special Issue: Who Is Afraid of the Microbes. Vol. 3, No. 5-1, 2015, pp. 8-13. doi: 10.11648/j.sjph.s.2015030501.12

\begin{abstract}
Phytochemical analysis and antimicrobial activities of hot water, hot and cold ethanol ethanolic extracts of the bark of Tabernaemontana pachysiphon Stapf. were assayed, using standard techniques. Escherichia coli (E. coli), Serratia marcescens (S. marcescens), Staphylococcus aureus (S. aureus), Alternaria solani (A. solani), Aspergillius niger (A. niger) and Penicilium notatum (P. notatum) were used as the challenge / test organism. Agar well and paper disc diffusion techniques were adopted. Results showed that the bacteria; E. coli, S. marcescens, S. aureus, were susceptible to both hot water and hot ethanol extracts respectively with zones of inhibition as follows: E. coli $(9,12 \mathrm{~mm})$ and $(10,15 \mathrm{~mm})$, S. marcescen $(9,9 \mathrm{~mm})$ and $(9,12 \mathrm{~mm}), S$. aureus $(8,9 \mathrm{~mm})$ and $(9,10 \mathrm{~mm})$, respectively. The fungus; $P$ notatum was susceptible to hot water, hot and cold ethanol extracts $(7.5,8,8 \mathrm{~mm})$ and $(7,7.5,7 \mathrm{~mm})$. A. solani and A. niger were resistant to the bioactivity of the extracts. The presence of active principles; alkaloids, anthraquinone, cardiac glycosides, poly phenol, saponins and tannins detected via the phytochemical screening may be responsible for the antimicrobial activities of the extracts.
\end{abstract}

Keywords: Stem Bark, Tabernaemontana pachysiphon, Bacteria, Fungus, Antimicrobial Activity, Phytochemical Analysis

\section{Introduction}

The lexicon of Biomedical literature are rich in natural ingredient of ethnobotanical origin called active principles. These ingredients not only serve the food and drug needs of man but have helped him to explore, master and control his environment. Crude plant extracts habour these active principles (phytochemicals) which have been implicated in biochemical and pharmaceutical formulations such as insecticides, herbicides, fungicides, bactericides as well as in food and food supplements [1]. Phytochemicals are organic compounds known in Biochemistry as secondary metabolites. They are mostly metabolic wastes stored within the body organs of higher plants [2].

According to [3], T. pachysiphon commonly called petepete in Igbo language belong to the Apocynaceae family. The matured plant is a medium sized tree of not more than 13 meters tall. They are usually, found among the luxuriant species of the fresh water wet lands of the tropical rain forest belt of Nigeria. They have simple leaves born on didymous branches. The bark is grayish - brown and the slash is yellowish white in colour.

The plants are monoecious, with, thick, fleshy, pentamerous flowers born on a pair of long firm, pedunculate cymose inflorescence. The fruit are paired globose, smooth textured berry with a furrow from stalk to apex. The mesocarp is a succulent mass of golden red pulp in which are embedded many ovoid dark brown to black seeds [3].

The bark and seed of this plant have been reported to contain conopharyngine and voacangine alkaloids. It has also been implicated in herbal remedies against breast inflammation in Benin. Dried leaves are pulverized and applied to sores and old ulcers for healing [4]. The dried leaves infusion did same against sores and ulcer [5]; while ethanolic extracts were found to be antimicrobial [6]. Driven by this information and the need for further exploitation of the wild plant, this study was therefore aimed at screening for the active principles as well as possible antimicrobial activity 
of crude extracts of its stem bark.

\section{Methodology}

\subsection{Study Area}

The study was conducted at the department of Biotechnology, Federal University of Technology, Owerri. Owerri is the capital city of imo state, South-Eastern Nigeria. It is located within latitude, $5^{\circ} 27^{\prime} \mathrm{N}$ and longitude $7^{\circ} 02^{\prime} \mathrm{E}$, in the tropical Rain forest belt of Nigeria.

\subsection{Collection and Preparation of Plant Material}

Periderm sections were slashed from a plant collected from the wild. The plant was identified as Tabernaemontana pachysiphon Stapf., at the department of Biological Sciences of the Federal University of Technology, Owerri, by an expert. The bark slashes were washed, air dried and preserved for the analysis.

\subsection{Test / Challenge Organisms}

Known stock cultures of the bacteria; Escherichia coli, Staphylococcus aureus, Serratia marcescens, used in the study, were obtained from Federal Medical Centre, Owerri, Imo state, Nigeria. The test fungi; Aspergillus niger, Alternaria solani and Penicilium notatum were obtained from Federal University of Agriculture, Umudike, Abia state, Nigeria. They were separately subcultured in nutrient agar (NA) and Sabourand Dextrose Agar (SDA) respectively. The pure cultures were stored at $4{ }^{\circ} \mathrm{C}$ for further studies.

\subsection{Culture Media}

Nutrient agar (NA) and Sabourand Dextrose Agar (SDA) were used for subculture and susceptibility testing.

\subsection{Extraction of Active Principles}

This followed the methods described by [7]. The bark slashes were chopped, washed and oven dried at $40^{\circ} \mathrm{C}$ till crispy, for seven days. The dried specimens were pulverized with an electric blender (Lexus Millenium Blender; SBG 320). The powder was transferred into a bottle and preserved for future use.

\subsection{Hot Ethanol Extraction}

This was done using Soxhlet extractor. Twenty grams (20 g) of the blended materials were weighed out and transferred into the thimble. The thimble was then inserted into the soxhlet extraction chamber and the extraction done for 24 hours with $100 \mathrm{ml}$ of absolute ethanol. The extracts obtained were concentrated. The paste was allowed to cool, poured into a sterile bottle, labeled and stored appropriately.

\subsection{Cold Ethanol extraction}

Twenty grams $(20 \mathrm{~g})$ of the bark powder was weighed out and transferred into a beaker and $100 \mathrm{ml}$ of absolute ethanol added. The mixture was agitated and allowed to extract at laboratory temperature for 48 hours. The mixture was then filtered into a conical flask, using Watman No. 1 filter paper. Alcohol was evaporated from the filtrate at $40^{\circ} \mathrm{C}$ on a hot plate. The extracts were then recovered and stored as thick paste for further used.

\subsection{Hot Water Extraction}

Ten grams (10 g) of the bark powder, were boiled in 100 $\mathrm{ml}$ of distilled water, for 1 hour. It was allowed to cool and filtered into a sterile bottle, labeled and stored appropriately.

\subsection{Phytochemical Screening}

The phytochemical screening followed the protocols described by $[8,9,10,11]$ :

\subsubsection{Alkaloids}

Five grams $(5 \mathrm{~g})$ of the bark powder were defatted for 2 hours with $100 \mathrm{ml}$ of diethyl ether in a Soxhlet apparatus. Aliquots, $0.5 \mathrm{~g}$ of the defatted powder were transferred into a $250 \mathrm{ml}$ volumetric flask and $200 \mathrm{ml}$ of $20 \%$ acetic acid ethanol was added. This was covered and allowed to stand for four hours. After which, it was filtered and the filtrate concentrated to a quarter $(1 / 4)$ of the original volume in a water bath at $40^{\circ} \mathrm{C}$. Drops of strong ammonium hydroxide were added until precipitation was completed. The setup was allowed to settle and the precipitate collected. Formation a white precipitate is positive result.

\subsubsection{Anthranoid}

Two hundred milligram $(0.2 \mathrm{~g})$ of the bark powder was boiled with $0.5 \mathrm{ml}$ of potassium hydroxide $(\mathrm{KOH})$ for 2 minutes in a test-tube, allowed to cool and filtered through cotton wool. Six (6) drops of acetic acid and $5 \mathrm{ml}$ of toluene were added to the filtrate and the mixture shaken for homogeneity. Two layers were formed and the upper layer was carefully pipetted into another test-tube $0.2 \mathrm{ml}$ of 0.5 mole of $(\mathrm{KOH})$ was added. A red coloration was indicative of the presence of Anthranoid.

\subsubsection{Anthraquinone}

A mixture of $5 \mathrm{~g}$ of the bark powder and $10 \mathrm{ml}$ of benzene was shaken vigorously and filtered through a whatman No. 1 filter paper. Five milliliters of $10 \%$ ammonia solution was added to the filtrate and shaken vigorously. The appearance of a pinkish or reddish color indicated the presence of anthraquinone.

\subsubsection{Cardiac Glycoside}

A mixture of $(5 \mathrm{~g})$ of the bark powder and $2 \mathrm{ml}$ of chloroform was shaken vigorously in a test-tube. Then $2 \mathrm{ml}$ of concentrated sulphuric acid was added and carefully shaken. The presence of reddish-brown coloration indicated the presence of cardiac glycoside.

\subsubsection{Phlobatannins}

Two grams ( $2 \mathrm{~g})$ of the bark powder was boiled with $5 \mathrm{ml}$ of $1 \%$ hydrochloric acid (HCL). The presence of reddish 
precipitate showed the presence of phlobatannnins.

\subsubsection{Polyphenol}

A mixture of $2 \mathrm{~g}$ of the bark powder and $10 \mathrm{ml}$ of distilled water was heated for 30 minutes, allowed to cool and filtered through cotton wool. One milliliter $(1 \mathrm{ml})$ of $1 \%$ potassium ferrocyanide was added to $1 \mathrm{ml}$ of the filtrate. A bluish green coloration indicated the presence of polyphenol.

\subsubsection{Saponins}

A mixture of $5 \mathrm{~g}$ of the bark powder and $5 \mathrm{ml}$ of distilled water was shaken vigorously in a test tube, to produce frothing and then boiled for 30 minutes at $60^{\circ} \mathrm{C}$. Persistence of the frothing indicated the presence of saponins.

\subsubsection{Tannins}

A mixture of $2 \mathrm{~g}$ of the bark powder and $10 \mathrm{ml}$ of distilled water in a test tube was stirred and filtered, using Whatman No. 1 filter paper. Ferric chloride was added to $2 \mathrm{ml}$ of the filtrate. A blue-black or grayish-blue precipitate indicated the presence of tannins.

\subsection{Preparation of Culture Media}

All culture media were prepared according to the manufacturer's instructions contained in the label of the container. The sterile molten agar media were allowed to cool to $40^{\circ} \mathrm{C}$, then poured into sterile petri dishes and allowed to solidify.

\subsection{Determination of Antimicrobial Activities}

This was done using standard microbiological procedure as described by [12]. Agar gel and paper disc diffusion techniques were used to determine the susceptibility of the test organisms to the respective crude extracts. The methods as described by [12] and used by [13, 14, 15] were used.

\subsubsection{Agar-Gel Diffusion Technique}

Broth culture of the log phase of the test organisms were seeded to the surface of the sterile gel and spread evenly with the aid of a bent sterile glass rod. Five wells of $8 \mathrm{~mm}$ diameter each, were made on the gel with the aid of a sterile cork borer. The cavities were then filled with the crude extracts, using sterile pipette. One hole was left empty while another was either filled with chloramphenicol (for bacteria) or nystatin (for fungi) to serve as negative and positive control respectively. The plates were incubated at $37^{\circ} \mathrm{C}$ for 24 hours and 14 days respectively, for the bacterial and fungal cultures. The observed zones of inhibition were measured using transparent metric rule.

\subsubsection{Disc Diffusion Method}

Circular discs of $7 \mathrm{~mm}$ diameter were punched out from Whatman No. 1 filter paper. The discs were wrapped in an aluminum foil and kept in a glass plate. The plates and the forceps were autoclaved for 15 minutes at $121^{\circ} \mathrm{C}$. The sterile paper discs were placed in petri dishes and impregnated with $0.2 \mathrm{ml}$ of the bark extracts using sterile pipette. They were then dried in hot air oven at $40^{\circ} \mathrm{C}$ for 20 minutes. A sterile wire loop was used to inoculate the agar plates with the test organisms. The respective impregnated discs were placed at different equidistant loci on the inoculated plates. The plates were then incubated upside down in an incubator set at $37^{\circ} \mathrm{C}$ for 24 hours for bacteria and 14 days for the test fungi.

Plates containing discs impregnated with chloramphenicol, nystatin and unimpregnated sterile paper discs were used as control. The observed zones of inhibition were measured with transparent metric rule.

\subsubsection{Minimum Inhibitory Concentration (MIC) Test}

The minimum inhibitory concentration test followed a modification of Akujobi et al. [16]. For the ethanolic extract, the concentration range of $50 \mathrm{mg} / \mathrm{ml}$ to $250 \mathrm{mg} / \mathrm{ml}$; corresponding to $1: 4$ to $1: 20 \mathrm{mg} / \mathrm{ml}$ of each bark extracts to peptone water, were used in the test. For the aqueous extract, homogenization was done with sterile distilled water.

The following concentrations were thereafter obtained and used: 50, 52.63, 55.56, 58.82, 62.50, 66.67, 71.43, 76.90, $83.30,90.90,100,111.10,125,142.85,167.60,200$ and 250 $\mathrm{mg} / \mathrm{ml}$. Three drops of overnight broth cultures of the respective test organisms were inoculated into the various dilutions. The bacterial cultures were then incubated at $37^{\circ} \mathrm{C}$ for 24 hours while fungal cultures were incubated for 7 days at $37^{\circ} \mathrm{C}$.

Growth for the bacteria was determined based on turbidity, using McFarland standard while that of fungi were based on percentage inhibitions of radial growth [17]. The lowest concentration of each of the extracts that inhibited the growth of the test organism was recorded as the MIC.

\subsubsection{Minimum Bactericidal / Minimum Fungicidal Concentrations (MBC/MFC) Test}

For the bacteria, tubes from the MIC test showing no visible growth were cultured on nutrient agar at $37 \mathrm{oC}$ for 24 hours. The lowest extract concentration with no observable growth was noted as the MBC while the MFC was determined by, $\frac{\mathrm{R} 1-\mathrm{R} 2}{\mathrm{R} 1} \times \frac{100}{1}[18]$.

Where: R1 is the control (Plate with the widest radius of proliferation

$\mathrm{R} 2$ is the plate with the shortest radius of proliferation

\subsubsection{Stastistical Analysis}

Data were analyzed using analysis of variance (ANOVA) SAS version 9.1. Means were separated with Duncan Multiple Range Test (DMRT) at P $>0.05$ as used by [19]. Results are presented in tables.

\section{Results and Discussion}

Results of the phytochemical screening are shown in Table 1. The zones of inhibitions of Escherichia coli, Staphylococcus aureus, Serratia marcescens, Aspergillus niger and Penicillium notatum are shown in Tables 2 ' $a$ ' and 'b'. The MIC, MBC and MFC are shown in Table 3. 


\subsection{Results}

Table 1. Result of the Phytochemical Analysis.

\begin{tabular}{ll}
\hline Test & Result \\
\hline Alkaloid & $+\mathrm{ve}$ \\
Anthranoids & $-\mathrm{ve}$ \\
Anthraquinone & $+\mathrm{ve}$ \\
Cardiac glycosides & $+\mathrm{ve}$ \\
Phlobatanin & $-\mathrm{ve}$ \\
Polyphenols & $+\mathrm{ve}$ \\
Saponin & $+\mathrm{ve}$ \\
Tannins & $+\mathrm{ve}$ \\
\hline
\end{tabular}

Legend:

+ve : present

-ve: absent

Table 2. Susceptibility Test Results.

A. Agar Gel Diffusion Test

\begin{tabular}{|c|c|c|c|c|c|c|}
\hline \multirow[t]{2}{*}{ Organism } & \multicolumn{6}{|c|}{ Zones of Inhibition Diameter (mm) } \\
\hline & HEE & CEE & HWE & CH & NY & EM \\
\hline Escherichia coli & 15 & - & 10 & 28 & - & - \\
\hline Staphylococcus aureus & 10 & - & 9 & 21 & - & - \\
\hline Alternaria solani & - & - & - & - & 22 & - \\
\hline Aspergillius niger & - & - & - & - & 18 & - \\
\hline \multicolumn{7}{|c|}{ B. Paper disc diffusion test. } \\
\hline \multirow[t]{2}{*}{ Organism } & \multicolumn{6}{|c|}{ Zones of Inhibition Diameter (mm) } \\
\hline & HEE & CEE & HWE & $\mathbf{C H}$ & NY & EM \\
\hline Escherichia coli & 12 & - & 9 & 27 & - & - \\
\hline Serratia marcescen & 9 & - & 9 & 21 & - & - \\
\hline Staphylococcus aureus & 9 & - & 9 & 20 & - & - \\
\hline Alternaria solani & - & - & 8 & - & 20 & - \\
\hline Penicillium notatum & 7 & 7 & 7 & - & 24 & - \\
\hline
\end{tabular}

Table 3. Minimum Inhibitory Concentration (MIC) and Minimum Bactericidal / Fungicidal Concentration (MBC / MFC) of the Bark Extracts of T. Pachysiphon.

\begin{tabular}{|c|c|c|c|c|c|c|c|c|c|}
\hline \multirow[t]{2}{*}{ Test organism } & \multicolumn{3}{|c|}{ MIC (mg / ml) } & \multicolumn{3}{|c|}{ MBC (mg / ml) } & \multicolumn{3}{|c|}{ MFC (mg / ml) } \\
\hline & HEE & CEE & HWE & HEE & CEE & HWE & HEE & CEE & HWE \\
\hline Escherichia coli & 125 & - & 200 & 125 & - & 200 & - & - & - \\
\hline Serratia marcescen & 166.6 & - & 200 & 166.6 & - & 200 & - & - & - \\
\hline Staphylococcus aureus & 166.6 & - & 250 & 166.6 & - & 250 & - & - & - \\
\hline Alternaria solani & - & - & - & - & - & - & - & - & - \\
\hline Aspergillius niger & - & - & - & - & - & - & - & - & - \\
\hline
\end{tabular}

Legend:

HEE: Hot ethanolic soxhlet extract

CEE: Cold ethanolic extract

HWE: Hot water extract

MIC: Minimum inhibitory concentration

MBC: Minimum Bactericidal concentration

MFC: Minimum fungicidal concentration

CH: Chloramphenicol ${ }^{\circledR}$

NY: Nystatin

EM: Empty hole

\subsection{Discussions}

The result of the phytochemical screening of the crude extracts of the bark of Tabernaemontana pachysiphon revealed the presence of active principles (Table 1) which are of medicinal importance. This corroborates the findings of 


\section{$[11,20,21]$}

The agar gel and paper disc diffusion tests showed that there was no inhibition on the growth of the two plant pathogenic fungi; Alternaria solani and Aspergillus niger by the three extracts this implies preparations with extracts of this plant will likely not be efficacious in curbing infections by these fungi. However, all the extracts were found to be active against Penicillium notatum with equal efficacy (Tables $2 \mathrm{a} \& \mathrm{~b}$ ). Hence different extracts of this plant will likely be efficacious in curbing infections by Penicillium notatum.

The test bacteria; Escherichia coli, Serratia marcescens, and Staphylococcus aureus were variably susceptible to the hot (ethanol and water) extracts (Tables 2a \& b) while showing $100 \%$ resistance to cold ethanol extract. The heating process may have helped to extract more active ingredient from the plant sample leading to high antibacterial activity. This corroborates with the report of [18].

From the results on Tables $2 \mathrm{a}$ and $\mathrm{b}$ respectively, it is clear that the diameters of zones of inhibition produced by the use of agar gel diffusion method of susceptibility testing are higher than those produced by the paper disc diffusion method. The inhibition pattern of the two techniques were similar, this implies that any of them could be used effectively for the susceptibility testing. However, the agar gel diffusion method should be preferable as it enhanced inhibition.

\section{Conclusion}

From this study, it has been revealed that ethanolic and hot water extracts of the bark of Tabernaemontana pachysiphon Stapf contain active phytochemicals; alkaloids, anthraquinone, cardiac glycosides, polyphenols, saponins and tannins. These active principles may be responsible for the antimicrobial activity of the crude extract. This is especially shown by the hot ethanol and hot water extracts which inhibited the growth of all the test bacteria as well as one of the test fungi; penicillium notatum in the agar gel and paper disc diffusion techniques.

From the fore going too, it is evident that the plant extracts contents can be formulated for use against diseases caused by any of the test bacteria as well as Penicillium notatum. The degree of efficacy may however, be below the standard antibiotic used in this study as positive controls.

\section{References}

[1] A. O. Ano, and C. I. Ubochi, "Phytochemical chemical composition of vegetable cowpea genotype. Advances in Science and Technology," vol. 1, issue 1, pp. 1-7, 2007.

[2] D. E. Okwu, "Evaluation of the chemical composition of indigenous species flavouring agent," Glob. Journal of pure and applied science, vol. 39, pp. 69-72, 2004.

[3] J. M. Dalziel, Useful plants of West Tropical Africa. Crown agents, London, 1995, pp. 341.
[4] H. M. Burkill, The useful plant of west Tropical Africa, $2^{\text {nd }}$ ed. The White Frairs press 1td, London, 1995, pp. 190-191.

[5] B.O. Green, Taxonomic and ethnobotanical studies on the family apocynaceae in Nigeria, PhD thesis, University of PortHarcourt, Nigeria, 1994.

[6] C.M. Duru and T.I. Mbata, "the antimicrobial activities and phytochemical screening of ethanolic leaf extracts of Hedranthera barteri Hook and Tabernaemontana pachysiphon Stapf," Journal of Bio and Tissue Eng, vol. 2, issue 1, Pp 1 - 4, 2010.

[7] AOAC (Association of official Analytical Chemist), Official methods of analysis, Gaithersburg, $15^{\text {th }}$ ed. M.D. USA, 2002, p 23.

[8] J.B. Harbone, "Phytochemical Methods, A guide to modern technique of plant analysis," Cambridge University press, Cambridge. UK, 1973, Pp 233.

[9] G. E. Trease, and I. C. Evans, "Pharmacognosy $12^{\text {th }}$ ed. Boinlliene Tinnal, London, 1989, pp 21-22.

[10] C. M Duru, T. I. Mbata, P. Ogu and U. Iheagwam, "The Antimicrobial activities and phytochemical screening of ethanolic leaf extracts of Hedranthera barteri and Tabernaemontana pachysiphon," World Journal of Biotechnology, vol. 10 issue 1, pp 1549-1553, 2009.

[11] C. M. Duru, C. A. Omenka, and A. M. Gaye, "Roll back aflatoxin: Ethnobotanical exclusion approach," Nig. Journal of Botany, vol. 25, issue 1, pp. 93-102, 2012.

[12] M. Cheesbrough, District laboratory practice in tropical countries, Part 2, Cambridge University Press, Uk, 2004

[13] I. K. Boakye-Yiadom, "Antimicrobial activity of two flavonone Isolate from the Camerounian plant Enythiana sigmoides," Planta Medicia, vol. 54, issue 2, pp. 126-212, 1979.

[14] C. A. Omenka, N. Ukagwu, B.A. Ali and C. C. Onyemenonce, "Antimicrobial activity and phytochemical analysis of Phyllantus niruri," Int. world J. Science and Tech, vol. 3, issue 1, Pp. $160-168,2004$.

[15] C. M. Duru, and N. E. Onyedineke, "Invitro study on the Antimicrobial activity and Phytochemical Analysis of Ethanolic Extracts of the mesocarp of Voacanga Africana. American Journal of Plant Physiology," vol. 5, issue 4, pp. $163-169,2010$.

[16] C. Akujobi, B. N. Anyanwu, C. Onyeze and V. I. Ibekwe, "Antibacterial activities and preliminary phytochemical screening of four medicinal plants," J. Appl. Sci., vol 7, issue 3, pp. $4328-4338,2004$.

[17] J.M. Whipps, "Effects of media on growth and interactions between a range of soil-borne grass pathogens and antagonistic fungi," New Pathologist, vol. 107 pp 127-142, 1987.

[18] C. M. Duru and B. E. Okoli, "Invitro Antimicrobial Assay and Phytochemical Analysis of aqueous and Ethanolic fruit Extracts of Voacanga Africana, " Int. J. Env. Health \& Human Dev. vol. 10, issue 1, pp. 24-30, 2009.

[19] K.A. Gomez and A.A. Gomez, Statistical procedure for agricultural Research, $2^{\text {nd }}$ ed. John Wiley and Sons, New York, 1984 , pp. 680. 
[20] M. Yusha' u, A. S. Kutama and F. U Sadsu, "Inhibitory activity of Annona squamosa extracts on bacterial isolates of Respiratory tract," Int. J. of Biological science, vol. 2, issue 4, $45-50,2010$.
[21] T. I, Mbata, C. M. Duru and H. A. Onwumelu, "Antibacterial activity of crude seed extracts of Buchholzia coriacea on some pathogenic bacteria,' J. Dev. Bio. Tissue Eng., vol. 1, issue 1, pp. 001-005, 2010. 